\title{
NORTH EAST DIVISION FOURTH ANNUAL CONFERENCE
}

\section{Psychiatry and the Law in Present Society}

The beautiful University of York provided the setting for this one-day conference held on 28 September 1979 and attended by 225 people. The audience included representatives of the police, prison service and legal profession as well as psychiatrists, nurses, psychologists and social workers.

The morning session was chaired by HIS HONOUR JUDGE G. BAKer and was opened by Professor Robert Bluglass. He posed the question whether psychiatry was still failing the mentally abnormal offender. With $£ 24,000,000$ allocated for Regional secure facilities and only $£ 3,000,000$ actually spent on them, continuing failure seemed likely. The need was for a range of units for the offender, and a flexible approach to their use. After-care was also deficient, and liaison between hospital and prison services needed improvement.

Professor Nigel Walker, Professor of Criminology at Cambridge, put forward a cogent case for the retention of the insanity defence and for its wider use in Magistrates' as well as Crown Courts. Insanity was more understandable to the lay person than 'diminished responsibility', but the McNaughton rules had proved unsatisfactory. Why not use the Napoleonic Code, 'if at the time of the crime the accused was mad, then there was no crime'? Utilizing the insanity defence should not necessarily lead to a Hospital Order-the Court should be free to make any appropriate recommendation. Professor Walker also touched on 'Unfit for Trial' or 'Found under Disability', a defence which he felt might also be extended to the Magistrates' Courts. This defence denied the accused a trial, but suitable cases might be deferred to allow for a period of treatment, or a 'trial of the facts' could be held, which might lead to acquittal if the offence was not proved.

The morning session was completed by MR PETER J. Lewis, a Senior Probation Officer, who reported on a study he had carried out on Psychiatric Probation Orders in the City of Nottingham. Some previous studies had revealed disappointing patterns of outcome, but his own study was more encouraging. Some psychiatrists had made such orders an opportunity to set up a multi-disciplinary treatment contract which involved the probation officers as well as the hospital team. Mr Lewis felt that these Orders could be made most useful with such collaboration and with planned contracts treatment understood by therapists, clients-and, of course, the Courts.

PROFESSOR WALKer chaired the afternoon session, which was opened by Professor JoHn GUNN, who reported on 'Changes in Grendon Prisoners'. Those receiving treatment at Grendon were older, more violent, had fewer family contacts and more 'form' than the average prisoners. In selecting people referred for Grendon, motivation (the prisoner's) was important, and consequently the hard-bitten, nonneurotic professional offender was usually rejected (about 25 per cent of all referrals). Ratings before and during treatment revealed that the Grendon milieu induced significant change. Prisoners became less neurotic, less hypochondriacal, depressed or anxious. Ego strength appeared to increase and hostility to diminish, and attitudes to prison officers and the police improved.

DR M. J. MCCuLLOCH next considered the management of the 'difficult, dangerous and delinquent patient', drawing on his experience at Park Lane Special Hospital. Difficult patients might be mainly violent or mainly unbiddable, and violence could be either reactive or spontaneous. Violence resulted from the complex interplay of events, mental illness and personality. Of 70 Park Lane patients examined, 29 had killed and 31 assaulted others. Those who killed or used knives were almost invariably schizophrenics or paranoid schizophrenics, and most were already known to the psychiatric service when the offence took place. Perhaps more adequate drug treatment could have prevented some of the violent crimes committed by such patients.

The final talk was from MR A. W. DRIScol, the Governor of Walton Prison, Liverpool. He likened doctors, policemen and prison officers to the AA patrolman-we patch people up and get them home. The problem for a lot of prisoners was to what sort of home they were to return. Mr Driscol attacked what he called the myth of the loving, caring family-most of his prisoners had never experienced one. The prison service now realized that it didn't really reform prisoners, and its members were starting to look at what they did more critically. Perhaps there was too much meeting of aggression with aggression, and of trying to counter cunning with even greater guile. The process of self-scrutiny was a painful one for the prison staff, but it was a necessary first step towards improving the service.

All the papers provoked lively discussion, and although forensic psychiatry isn't a particular personal interest I felt I could rate all of them between good and excellent. I listened, learned and was stimulated by what I heard. 'Don't reject the difficult patient' pleaded Dr McCulloch, and I hope everyone remembered that as they left this well-organized conference, which reflected great credit on Hugh de B. Warren, who planned the programme, Alan Stephens, our longsuffering Divisional Secretary, and all who took part.

GARRY BLESSED

[Contributions and reports of meetings or other activities in the Divisions which are likely to be of interest to the membership as a whole are always welcome-Editor.] 